\title{
Habitat-specific size structure variations in periwinkle populations (Littorina littorea) caused by biotic factors
}

\author{
Nina Eschweiler • Markus Molis • Christian Buschbaum
}

Received: 29 February 2008 / Revised: 23 September 2008 / Accepted: 24 September 2008 / Published online: 15 October 2008 (C) Springer-Verlag and AWI 2008

\begin{abstract}
Shell size distribution patterns of marine gastropod populations may vary considerably across different environments. We investigated the size and density structure of genetically continuous periwinkle populations (Littorina littorea) on an exposed rocky and a sheltered sedimentary environment on two nearby islands in the south-eastern North Sea (German Bight). On the sedimentary shore, periwinkle density $\left(917 \pm 722\right.$ individuals $\left.\mathrm{m}^{-2}\right)$ was about three times higher than on the rocky shore $\left(296 \pm 168\right.$ individuals $\left.\mathrm{m}^{-2}\right)$. Mean $(9.8 \pm 3.9 \mathrm{~mm})$ and maximum ( $22 \mathrm{~mm}$ ) shell size of $L$. littorea on the sedimentary shore were smaller than on the rocky shore $(21.5 \pm 4.2$ and $32 \mathrm{~mm}$, respectively), where only few small snails were found. Additionally, periwinkle shells were thicker and stronger on the rocky than on the sedimentary shore. To ascertain mechanisms responsible for differences in population structures, we examined periwinkles in both environments for growth rate, predation pressure, infection with a shell boring polychaete (Polydora ciliata) and parasitic infestation by trematodes. A crosswise transplantation experiment revealed better growth conditions on the sedimentary than on the rocky shore. However, crab abundance and prevalence of parasites and $P$. ciliata in adult snails were higher on the sedimentary shore. Previous investiga-
\end{abstract}

Communicated by H.-D. Franke.

N. Eschweiler · C. Buschbaum ( $₫)$

Wadden Sea Station Sylt, Alfred Wegener Institute for Polar and

Marine Research, Hafenstrasse 43, 25992 List/Sylt, Germany

e-mail: Christian.Buschbaum@awi.de

M. Molis

Section Seaweed Biology, Biologische Anstalt Helgoland, Alfred Wegener Institute for Polar and Marine Research, Kurpromenade 201, 27498 Helgoland, Germany tions showed that crabs prefer large periwinkles infested with $P$. ciliata. Thus, we suggest that parasites and shell boring $P$. ciliata in conjunction with an increased crab predation pressure are responsible for low abundances of large periwinkles on the sedimentary shore while high wave exposure may explain low densities of juvenile L. littorea on the rocky shore. We conclude that biotic factors may strongly contribute to observed differences in size structure of the L. littorea populations studied on rocky and sedimentary shores.

Keywords Comparative ecology · Marine snails · Parasites · Population structure

\section{Introduction}

Grazing gastropods are important structuring elements of intertidal communities (e.g. Hawkins and Hartnoll 1983; Anderson and Underwood 1997). Specifically, periwinkles affect benthic community structure and recruitment success of structurally important seaweeds (Lubchenco 1978; Janke 1990; Wilhelmsen and Reise 1994; Albrecht 1998; Buschbaum 2000; Trussell et al. 2002, 2003). The ecological effect of periwinkles may vary with body size. For instance, periwinkles display size-dependent grazing rates (Geller 1991), reduced intra-specific competition in smaller size categories (Byers 2000), and differential habitat selection by age (Saier 2000). Consequently, factors causing variation in size distribution of periwinkles are important for community dynamics in coastal environments.

In different marine systems, genetically continuous gastropod and bivalve populations may show strong phenotypic plasticity in the size and strength of shells (e.g. Seed 1968; Harger 1970; Bayne and Worrall 1980; Seed and 
Suchanek 1992; Reid 1996). Wave exposure is considered one of the most important factors affecting gastropod shell size distribution. For example, Hylleberg and Christensen (1978) showed that average shell size of the periwinkle Littorina littorea (L.) increased with increasing degree of exposure. Presumably, a large shell size in conjunction with a large aperture enables an increased foot size for greater adhesion to the substratum and enhanced ability to withstand wave shock (Raffaelli 1982). Other factors may be likewise important for determining the size structure of marine gastropod populations, e.g. food availability and intraspecific competition (Kemp and Bertness 1984; Fenske 1997), predation pressure (Palmer 1990; Yamada et al. 1998; Trussel 1996; Trussel and Nicklin 2002; Buschbaum et al. 2007), parasitism (Lauckner 1984; Huxham et al. 1993) and overgrowth by epibionts (Wahl 1996; Buschbaum and Reise 1999; Thieltges and Buschbaum 2007).

In this study we investigated the size distribution of two populations of the periwinkle L. littorea (L.) in contrasting environments in the south-eastern North Sea (German Bight). We chose the exposed rocky shore of the island of Helgoland and a sheltered soft sediment environment near the island of Sylt as study areas. At both sites, genetically identical populations of the periwinkle L. littorea (Wilhelmsen 1998) reach high densities of hundreds of individuals per square metre (Janke 1990; Wilhelmsen and Reise 1994; Buschbaum 2002; Reichert and Buchholz 2006).

Our first step was to establish the shell morphology and the size and density distribution of L. littorea on the exposed rocky and sheltered sedimentary shores. We hypothesised that in addition to exposure, biotic factors differ between the two environments and might potentially contribute to differences in population structures of $L$. litto$r e a$. To test this hypothesis, we investigated simultaneously (1) the growth rate of L. littorea, (2) predator abundance, (3) prevalence of periwinkle parasitizing trematodes and (4) infection with the shell boring polychaete Polydora ciliata (Johnston).

\section{Materials and methods}

\section{Study sites}

We selected two field sites for our comparative investigations: wave protected mussel beds on the soft sediment tidal flats near the island of Sylt $\left(55^{\circ} 02^{\prime} \mathrm{N}, 8^{\circ} 26^{\prime} \mathrm{E}\right)$ and the exposed rocky offshore island of Helgoland $\left(54^{\circ} 11^{\prime} \mathrm{N}\right.$, $07^{\circ} 53^{\prime} \mathrm{E}$ ) (Fig. 1). Both sites are located in the south-eastern North Sea and linked by currents enabling exchange of pelagic larvae of benthic organisms (Giménez and Dick 2007). They represent fundamentally different environments with respect to abiotic and biotic conditions.

At Sylt, mean annual water temperature is about $9^{\circ} \mathrm{C}$, with a summer average of $15^{\circ} \mathrm{C}$ and a winter average of $5^{\circ} \mathrm{C}$. Tides are semi-diurnal and average tidal range is about $2 \mathrm{~m}$. Average salinity is 30 . The area is protected from prevailing westerly (onshore) winds and waves by sand dunes.
Fig. 1 Study areas in the southeastern part of the North Sea. Investigations and field experiments were performed on mixed beds of blue mussels Mytilus edulis and oysters Crassostrea gigas in the north of the island of Sylt and on the rocky shore of the island of Helgoland (marked by black arrows)

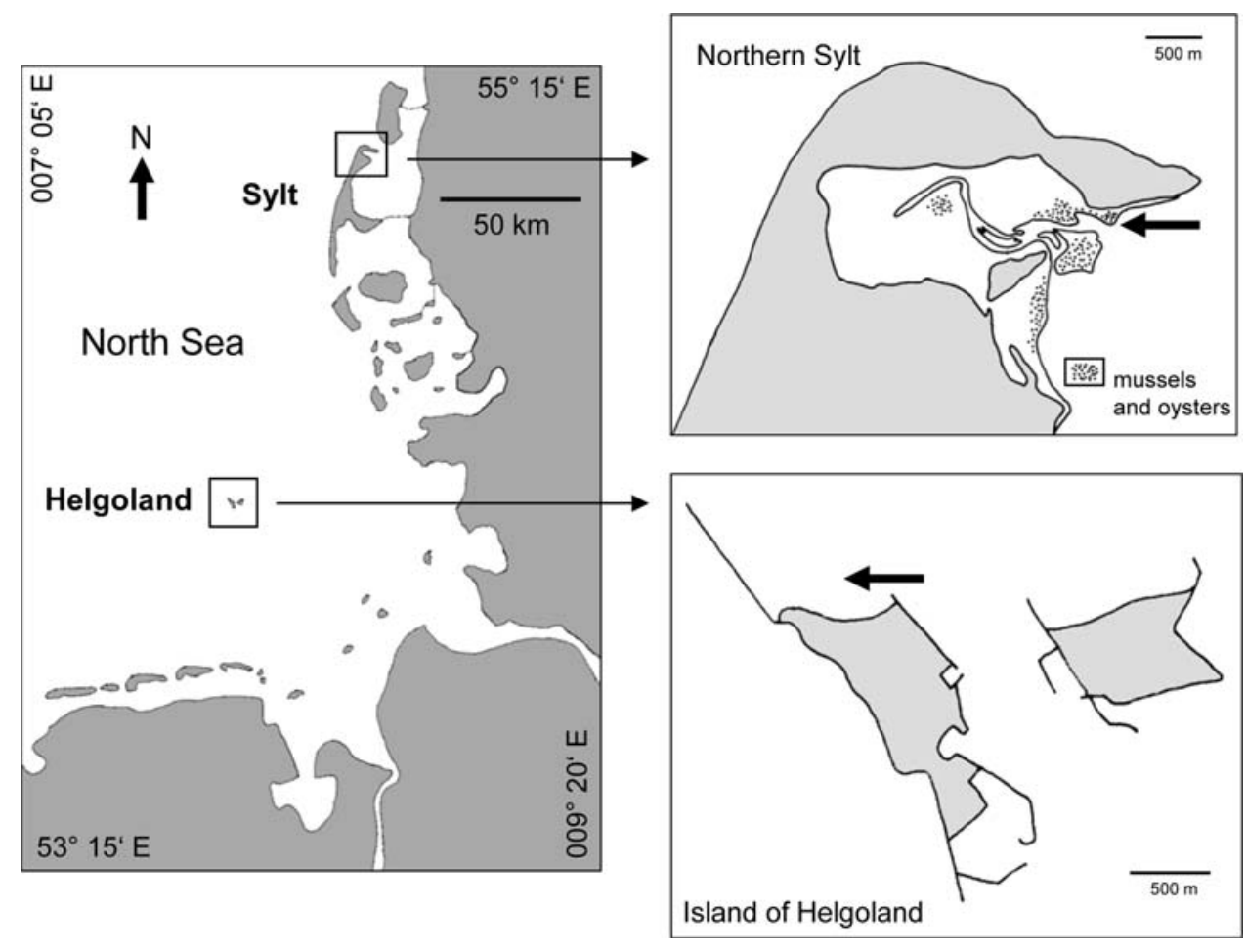


Detailed descriptions of the geology, hydrography and sediments of the study area are given by Reise (1985), Austen (1992, 1994a, b), Bayerl and Higelke (1994) and Reise et al. (1994). In the Wadden Sea, periwinkles L. littorea reach highest densities on mixed epibenthic aggregations of the non-indigenous Pacific oyster Crassostrea gigas (Thunberg) and the native blue mussel Mytilus edulis L. which represent preferred habitats for periwinkles because bivalve aggregations provide an appropriate attachment substratum and suitable food conditions.

The island of Helgoland represents the only rocky shore in the southeastern part of the North Sea. The island is located $<100 \mathrm{~km}$ south-west of the island of Sylt. Here, average tidal range is about $2.3 \mathrm{~m}$, mean water temperatures are $13^{\circ} \mathrm{C}$ in summer and $7^{\circ} \mathrm{C}$ in winter at an average salinity of 32. Blue mussels and the Pacific oyster occur at a low density on the macroalgae-dominated intertidal at Helgoland. More detailed descriptions of the ecology, geology and of abiotic factors are given by Hagmeier (1930), Wurster (1962), Janke (1986, 1990), Bartsch and Tittley (2004) and Reichert and Buchholz (2006).

\section{Size and abundance of $L$. littorea}

Periwinkles were collected between July and August 2006 during low tide using identical methods at both study sites. To investigate periwinkle densities and their size distribution in different tidal zones a stratified random sampling design was used. Snails were collected in the mid intertidal zone (emersion time about $4 \mathrm{~h}$ ), low intertidal (emersion time about $2 \mathrm{~h}$ ) and in the shallow subtidal zone. A plastic ring with a diameter of $20 \mathrm{~cm}$ (corresponding to an area of $0.03 \mathrm{~m}^{2}$ ) was placed randomly on the bottom. All snails inside the ring were counted and grouped into 5 size categories (measured from aperture to apex, Fig. 2): (1) 1$8 \mathrm{~mm}$, (2) $>8-12 \mathrm{~mm},(3)>12-18 \mathrm{~mm}$, (4) $>18-22 \mathrm{~mm}$, (5) $>22 \mathrm{~mm}$. At each tidal level six replicate samples were taken.

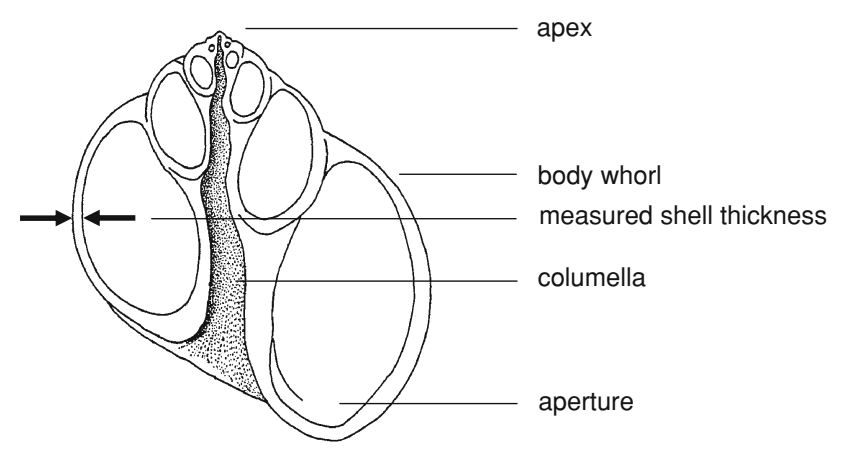

Fig. 2 Measurement of shell thickness (mm) of Littorina littorea
Shell strength

In August 2006, we collected snails of the same size range $(15-19 \mathrm{~mm})$ at both study sites. Before investigating shell strength snails were inspected for infection with $P$. ciliata. This shell boring polychaete may strongly decrease periwinkle shell strength (Buschbaum et al. 2007). Thus, only non-infested snails were used for shell strength comparisons ( $n=45$ snails per site). To determine the force necessary to break periwinkle shells, investigations were performed with the same methods and measuring device used by Buschbaum et al. (2007), which allows estimation of general shell strength by measuring the force required to crack shells in one particular plane.

\section{Shell thickness}

To determine shell thickness of periwinkles originating from Sylt and Helgoland, 20 periwinkles from 17 to $19 \mathrm{~mm}$ shell height were collected at each site and boiled in order to remove the soft body from the shell. A moulding cutter was used to bisect the shells. Afterwards, snail shell thickness was measured to the nearest $0.01 \mathrm{~mm}$ using a stereomicroscope fitted with an ocular micrometer (see Fig. 2).

\section{Snail growth experiments}

In a reciprocal transplantation experiment, we measured shell height increment of $L$. littorea at both sites from April/May until October 2006. At both Sylt and Helgoland, juvenile snails of a size range from 9.5 to $12 \mathrm{~mm}$ shell height were collected. This size class was used because length increments of larger organisms might be too small to detect effects of periwinkle origin and location of growth on L. littorea shell increment. Furthermore, shells of larger specimens were often eroded, potentially confounding length measurements with shell degradation.

To test whether snail origin and site where periwinkles matured affects growth rate in L. littorea, snails collected at Sylt and Helgoland were marked with differently coloured nail varnish and transplanted to the mid intertidal zone of both sites. We corralled the snails in closed cages $(20 \mathrm{~cm}$ in diameter, $25 \mathrm{~cm}$ in height) made of polyethylene mesh wire (mesh size $0.5 \mathrm{~cm}$ ) and a polyvinyl chloride (PVC) bottom plate. Altogether, we used 16 cages per study site. At both sites, eight cages each with ten snails originating from Helgoland and eight cages each with ten snails collected near Sylt were installed.

On the rocky island of Helgoland cages were fixed using dowels and screws while at Sylt cages were fixed with iron rods on mixed beds of $C$. gigas and M. edulis. Snail size was measured at the beginning and at the end of the experiment to the nearest $0.01 \mathrm{~mm}$ using callipers, and shell 
increment was calculated as the difference between both measurements.

At the beginning of the experiment, mean shell height of L. littorea from both habitats did not differ significantly from each other.

Predator densities

In the soft sedimentary environment of the Wadden Sea, periwinkles are mainly consumed by green crabs (Carcinus maenas L.), while on the rocky shore of the island of Helgoland both green crabs and edible crabs (Cancer pagurus L.) prey on L. littorea (Scherer and Reise 1981; Buschbaum et al. 2007; own observations).

We used the same method to determine crab abundances on intertidal beds of oysters and mussels on the sandy shore and in the intertidal zone of the rocky environment. In August 2006, all crabs inside a randomly selected area of $1 \mathrm{~m}^{2}(n=12)$ were collected, counted and their carapace width was measured to the nearest $1 \mathrm{~mm}$ using calliper.

Infection with shell boring $P$. ciliata and trematode parasites

At each site, 56 snails were randomly collected to study the infection rate with shell boring polychaetes $P$. ciliata; we also collected 75 periwinkles at each site to investigate the prevalence of digenean trematodes. Since both, $P$. ciliata and trematodes occur exclusively in periwinkles $\geq 12 \mathrm{~mm}$ shell height (Lauckner 1984; Buschbaum et al. 2007; Thieltges and Buschbaum 2007), only individuals of this size range were sampled.

To assess the prevalence of shell boring polychaetes, we determined the presence of living $P$. ciliata for each snail. In the laboratory, periwinkles were placed in separate Petri dishes for $1 \mathrm{~h}$ prior to visual inspections with a stereo microscope; the $1 \mathrm{~h}$ in water allowed live $P$. ciliata to extend from shells. Periwinkles hosting living polychaetes were considered to be infested.

Tissue-inhabiting trematodes utilise L. littorea as first intermediate hosts and are commonly associated with periwinkles (Lauckner 1984). To determine the prevalence of trematodes, periwinkle shells were carefully cracked with a hammer and the entire soft body of each snail was checked for trematodes under a stereo microscope.

Mean prevalence of trematodes and P. ciliata (\% infected snails from total sample) was calculated for the rocky and sedimentary shores.

\section{Statistical analyses}

Results are presented as arithmetic mean \pm standard deviation. Data of the growth experiment were analysed by using a two-factorial ANOVA, with location of growth (two levels) and snail origin (two levels) as fixed factors. The Tukeyhonest-significant-difference-test (HSD) was used for pairwise multiple comparisons of the growth experiment. Homoscedasticity of untransformed data was confirmed by Cochrans's test. Comparisons of periwinkle abundance and shell size, snail shell strength and thickness and predator abundance between both sites were analysed by MannWhitney $U$ test. Differences in prevalence of trematodes and $P$. ciliata were analysed using Chi-square tests. Effects were considered to be statistically significant if $P<0.05$.

\section{Results}

Size and abundance of $L$. littorea in sedimentary versus rocky shore sites

Mean shell size and density of L. littorea differed significantly between the sedimentary and rocky shore. On the sedimentary shore, mean periwinkle shell size $(9.8 \pm 3.9 \mathrm{~mm})$ was considerably smaller than on the rocky shore $(21.5 \pm 4.2 \mathrm{~mm}, U$ test, $P<0.0001)$. The reverse pattern was observed for mean snail density. Abundance of $L$. littorea was about three times higher on the sedimentary shore $\left(917 \pm 722\right.$ individuals $\left.\mathrm{m}^{-2}\right)$ than on the rocky shore (296 \pm 168 individuals $\mathrm{m}^{-2}, U$ test, $\left.P<0.001\right)$.

Zonation pattern of L. littorea size classes

On the sedimentary shore, small periwinkles (size classes 0-8 and >8-12 $\mathrm{mm}$ shell height) reached highest abundances of about 1,500 individuals $\mathrm{m}^{-2}$ in the mid intertidal zone, whereas larger specimens from 12 to $22 \mathrm{~mm}$ (size classes $>12-18$ and $>18-22 \mathrm{~mm}$ ) were more abundant in the low intertidal and shallow subtidal zones (Fig. 3a). Snails of $>22 \mathrm{~mm}$ shell height were not found in the sedimentary environment.

On the rocky shore, juvenile snails from 0 to $8 \mathrm{~mm}$ shell height were not found. Only a comparatively low number of L. littorea from $>8$ to $12 \mathrm{~mm}$ was detected in all three tidal zones (Fig. 3b). Abundance of snails from $>12$ to $18 \mathrm{~mm}$ shell height was much lower at the rocky shore than at the sedimentary shore in all three tidal zones. Periwinkles larger than $18 \mathrm{~mm}$ shell height (size classes $>18-22$ and $>22 \mathrm{~mm}$ ) were more abundant on the rocky shore and were underrepresented on the sedimentary shore.

\section{Shell strength and thickness of L. littorea}

The mean force expended to crush periwinkles from Helgoland was $292 \pm 88$ Newton, whereas a mean force of $255 \pm 106$ Newton was necessary to crack shells of $L$. littorea 

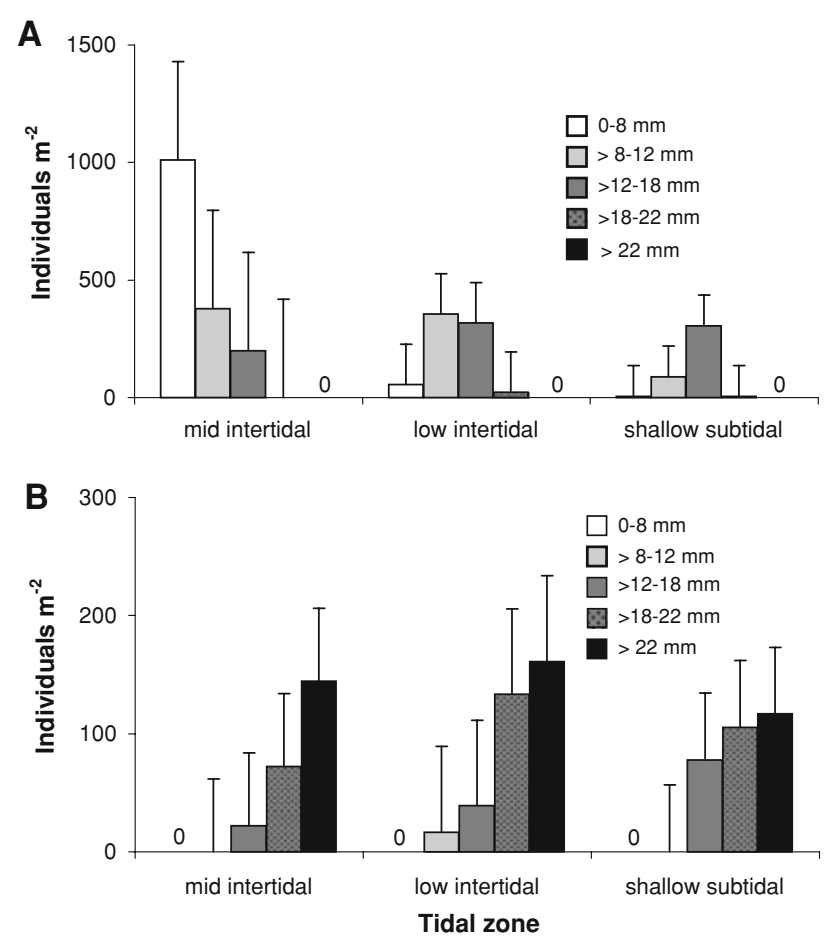

Fig. 3 Mean abundance $( \pm \mathrm{SD})$ of different size classes of Littorina littorea in the mid intertidal, low intertidal and shallow subtidal zone on mussel beds of the sedimentary shore at Sylt (a), and on the rocky shore at Helgoland (b). At each tidal level, six replicate samples $(n=6)$ were taken. Zeros indicate complete lack of periwinkles

from Sylt. However, this difference in shell strength was not statistically significant ( $U$ test, $P=0.0617, n=45$ ).

Shell thickness of $L$. littorea differed significantly between study sites. Mean shell thickness of the first (body) whorl (see Fig. 2) was $0.81 \pm 0.14 \mathrm{~mm}$ in periwinkles of the sedimentary shore and $1.03 \pm 0.06 \mathrm{~mm}$ in snails from the rocky shore ( $U$ test, $P<0.0001, n=20$ ).

\section{Snail growth experiments}

Both location of growth and snail origin had significant effects on $L$. littorea shell height increment (Table 1; Fig. 4). First, snails originating from both shores had greater shell height increment in the sedimentary environment than on the rocky shore. Second, shell height increment of snails from Sylt was significantly reduced in comparison to shell height increment of periwinkles from Helgoland in both the rocky as well as in the sedimentary environment. Thus, these results indicate that growth conditions for periwinkles are more favourable at the sedimentary shore while specimens from the rocky shore have a faster growth rate. We did not detect significant interactions between origin of snails and location of growth (Table 1).

While $L$. littorea originating from and growing on the rocky shore attained a shell increment of $7.29 \pm 0.84 \mathrm{~mm}$,
Table 1 Results from $2 \times 2$ ANOVA on growth rates of periwinkles Littorina littorea originating from either a sedimentary (Sylt) or a rocky shore (Helgoland) and growing either in the original or, after transplantation, in the other site $(n=8)$

\begin{tabular}{lllrl}
\hline Source & $d f$ & MS & \multicolumn{1}{l}{$F$} & $P$ \\
\hline Periwinkle origin & 1 & 9.39 & 14.11 & 0.0009 \\
Location of growth & 1 & 3.90 & 5.86 & 0.0228 \\
$\begin{array}{l}\text { Periwinkle origin } \times \\
\text { location of growth }\end{array}$ & 1 & 0.54 & 0.81 & 0.3744 \\
\hline
\end{tabular}

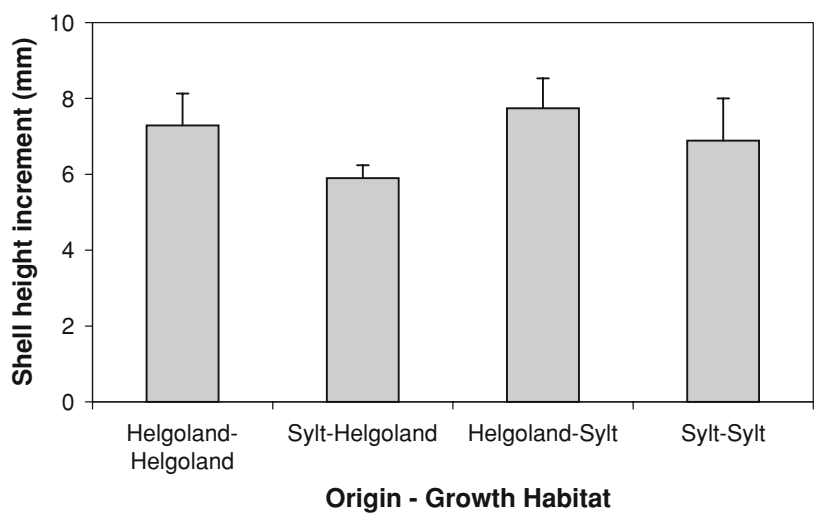

Fig. 4 Mean shell height increment $( \pm \mathrm{SD})$ of Littorina littorea (initial length of 9.5-12 $\mathrm{mm}$ ) in a 6 months long cross transplantation experiment on the rocky shore of Helgoland and sedimentary shore near Sylt in 2006. First mentioned site stands for snail origin and second mentioned site indicates location after transformation

periwinkles originating from the sedimentary shore and transplanted to the rocky shore showed a shell increment of $5.90 \mathrm{~mm} \pm 0.34$ (Tukey's test, $P=0.014$, Fig. 4).

Snails from the rocky shore transplanted to the sedimentary environment had a shell increase of $7.74 \pm 0.79 \mathrm{~mm}$, which was not significantly different from shell height increment of $L$. littorea originating and growing on Sylt $(6.89 \pm 1.11 \mathrm{~mm}$, Tukey's test, $P>0.05$, Fig. 4$)$.

A further statistical difference was detected between growth increment of periwinkles from Sylt growing on Helgoland and snails from Helgoland transplanted to Sylt (Tukey's test, $P=0.001$, Fig. 4). All other pairwise comparisons were not significant (Tukey's test, $P>0.05$ ).

Predator density

Mean density of predatory crabs (C. maenas) on epibenthic beds of oysters and mussels near Sylt $(5.6 \pm 2.8$ individuals $\mathrm{m}^{-2}$ ) was significantly higher than mean predator density (C. maenas and C. pagurus) on the rocky shore of Helgoland ( $3.0 \pm 2.5$ individuals $\mathrm{m}^{-2}, U$ test, $\left.P=0.018, n=12\right)$. On Helgoland, mean density of $C$. maenas and $C$. pagurus were $2.5 \pm 2.2$ and $0.5 \pm 0.9$ individuals $\mathrm{m}^{-2}$, respectively. 
Predatory green crabs were larger on the sedimentary shore, i.e. carapace width of $C$. maenas on Sylt (51 $\pm 16 \mathrm{~mm}, n=67)$ was significantly larger than on the rocky shore ( $34 \pm 19 \mathrm{~mm}, n=31)$ ( $U$ test, $P=0.032$ ). Edible crabs $C$. pagurus on the rocky island of Helgoland showed a mean carapace width of $92 \pm 13 \mathrm{~mm}$.

Infection with trematode parasites and shell boring $P$. ciliata

We detected a significantly higher prevalence of digenean trematodes in adult L. littorea from the sedimentary shore (22.9\%) compared to the rocky shore (1.4\%) (Chi-square test, $P=0.001, n=75$ ). Three species of digenean trematodes were detected: Renicola roscovita (Stunkard), Himasthla elongata (Mehlis) and Cryptocotyle lingua (Creplin).

We found a significantly higher prevalence of the shell boring polychaete $P$. ciliata in L. littorea collected on the sedimentary shore of Sylt $(25.0 \%)$ than in periwinkles from Helgoland (3.6\%, Chi-square test, $P=0.001, n=56$ ). On Helgoland we detected only $P$. ciliata in periwinkles $>22 \mathrm{~mm}$ shell height, while on the sedimentary shore of Sylt smallest $L$. littorea infested with $P$. ciliata had a shell size of $13 \mathrm{~mm}$.

\section{Discussion}

Density, size distribution pattern and shell morphology of L. littorea were very different between the exposed rocky shore of the island of Helgoland and the sheltered sedimentary shore of the island of Sylt. Total snail density was about three times higher on mixed beds of mussels $M$. $e d u$ lis and oysters $C$. gigas in the sedimentary environment than on the rocky shore. While small periwinkles were responsible for high $L$. littorea densities on the sedimentary shore, larger snail size classes dominated the rocky shore.

Our studies on shell size distribution across the tidal gradient revealed a specific zonation pattern of $L$. littorea size classes on the sedimentary shore. We detected high abundances of small snails in the mid intertidal zone while larger perwinkles mainly occurred in the low intertidal and shallow subtidal zone. Saier (2000) attributed this pattern to high crab predation on juvenile snails in the subtidal zone and to preferential periwinkle settlement in the intertidal zone to prevent crab predation. On the rocky shore, by contrast, periwinkle size classes were more equally distributed indicating that predation and active habitat choice of juvenile snails are of minor importance and do not determine a specific periwinkle size distribution along the tidal gradient.

It is surprising that large periwinkles were underrepresented on the sedimentary shore because our experiments revealed that growth conditions for $L$. littorea are more favourable in the sedimentary environment. Multiple factors seem to be responsible for the observed differences in morphology and population structure of $L$. littorea between both environments.

\section{Shell morphology of L. littorea}

Shell morphology is one of the most important traits controlling susceptibility to predation in molluscs (Hadlock 1980; Trussel and Nicklin 2002; Buschbaum et al. 2007). Shells of periwinkles from Sylt were thinner and weaker than those of Helgoland conspecifics. Additionally, periwinkles from Helgoland showed a higher shell height increment than snails from Sylt in both environments indicating genetic heterogeneity. However, using allozyme analysis Wilhelmsen (1998) did not find genetic differences between the investigated $L$. littorea populations on the rocky shore of the island of Helgoland and the sedimentary shore near the island of Sylt. It is a common pattern that gastropod species with pelagic eggs and planktotrophic veliger larvae are widely dispersed. This ensures high levels of gene flow throughout large populations and any small-scale differences in selection are swamped by recruitment from a wider area (Janson 1987; Reid 1996). This is also true for the periwinkle $L$. littorea because its veliger larvae spend 4-7 weeks in the water column before settling on the bottom (Fretter and Graham 1980; Janson 1987). Both Sylt and Helgoland are located within the same water body. Their proximity is less than $100 \mathrm{~km}$ and they are linked via water currents that allow the exchange of larvae of benthic organisms (Giménez and Dick 2007). This indicates that a genetic exchange between both periwinkle populations is very likely. Thus, several other factors than genetic differences seems to be responsible for phenotypic variations in the studied L. littorea populations.

First, Kemp and Bertness (1984) documented that strength and thickness of periwinkle shells may strongly depend on snail growth rates. Fast growing L. littorea developed thinner shells with more volume to accommodate more body mass than slower growing specimens. Additionally, rapid growth may limit the rate at which shell material can be deposited (Reid 1996). We did not measure body mass, but used shell size increment as a proxy for growth rates. The difference in periwinkle shell increment between the rocky and sedimentary site may result from high food availability on the soft bottom (e.g. benthic diatoms and green algae such as Ulva spp.) and/or a limited time available for feeding due to strong wave action on the exposed rocky shore (Brown and Quinn 1988; Wilhelmsen and Reise 1994; Reid 1996; Fenske 1997). Thus, faster growth may be responsible for thinner and weaker periwinkle shells in L. littorea living on bivalve aggregations in the Wadden Sea. Our results are in concordance with investiga- 
tions of Hylleberg and Christensen (1978) performed in Limfjord, Denmark. They also found that shells of L. litto$r e a$ are thicker on more exposed shores and claim that thick shells are an adaptation to resist the mechanical impact of waves.

Second, predator-induced increases in shell thickness of L. littorea (Trussel and Nicklin 2002) and other littorinids (Raffaelli 1982) have been reported. In contrast to our study, Raffaelli (1982) found that shells of L. saxatilis and L. nigrolineata were thicker at sheltered than at exposed sites because predator abundance and, thus, the degree of induced morphological anti-predator responses in snails, is often higher in sheltered than in exposed areas. However, despite the higher crab abundance in conjunction with higher predation pressure on the sheltered sedimentary shore in this study, periwinkles produced comparatively weak and thin shells. Thus, predator abundance and pressure seem to be of minor importance for shell morphology of $L$. littorea at our study sites.

Third, different shell morphologies may result from different levels of intra-specific competition. Competition for food, resulting from high population densities has been shown to affect variation in snail size (Sherrell 1981). Furthermore, Kemp and Bertness (1984) showed that in dense snail populations with slow individual growth rate, periwinkles have elongate and thicker shells in comparison to specimens with rounder, globose shells in sparse populations. However, despite high densities of periwinkles on the sedimentary shore, L. littorea did not show any shell characteristics of a snail population with slow-growing individuals (own observations). Additionally, Fenske (1997) supposed that available resources in the Wadden Sea at Sylt are sufficient to maintain a high population density of L. littorea and rejected the possibility of intraspecific competition.

\section{Indirect effects on population structure of L. littorea}

At the sedimentary shore, we found a higher prevalence of both trematode parasites and shell boring polychaetes $(P$. ciliata) in L. littorea compared to periwinkles originating from the rocky shore of Helgoland. The association with both trematodes and shell boring polychaetes may largely account for the observed lower abundance of large L. littorea on the sedimentary shore compared to the rocky shore, because both organisms are known to have multiple detrimental effects on periwinkles.

Among metazoans, trematodes are the most common parasites of intertidal organisms and their complex life cycles almost always involves a gastropod as first intermediate host (Mouritson and Poulin 2002). Trematodeinfected $L$. littorea have a higher mortality than uninfected specimens (Huxham et al. 1993; Mouritson and Poulin 2002). Furthermore, infected periwinkles have a reduced mobility. Following grazing migrations during low tide parasitized periwinkles might be too slow to find sheltered sites and, thus, might experience higher predation pressures by crabs approaching with the incoming tide. Moreover, parasitized snails might arrive late at snail aggregations where they are consequently situated at the periphery. This will make them more susceptible to crab predation because of a higher probability of being among the first-encountered individuals (Davies and Knowles 2001).

Not all size classes of L. littorea are equally infected with trematode parasites. Lauckner (1984) showed that periwinkles below $12 \mathrm{~mm}$ shell height are not infested and that prevalence of parasites increases with increasing shell height. Thus, trematode parasites cause mortality predominantly in larger snails and may be one important factor for low abundances of snails above $18 \mathrm{~mm}$ shell height on the sedimentary shore.

Similarly, the prevalence of shell boring polychaetes $P$. ciliata is also higher in large-sized L. littorea and may be about $70 \%$ in snails above $18 \mathrm{~mm}$ shell height on soft bottoms in the northern Wadden Sea (Buschbaum et al. 2007; Thieltges and Buschbaum 2007). Whether an infestation with $P$. ciliata leads directly to an increased mortality in $L$. littorea is unknown. However, periwinkles infested with shell boring polychaetes have a greatly reduced shell strength and are preferentially eaten by shore crabs $C$. maenas (Warner 1997; Buschbaum et al. 2007). This indirect effect also affects large periwinkles that are normally outside the food spectrum of $C$. maenas and, therefore, infestation with $P$. ciliata may prevent a size refuge for $L$. littorea (Buschbaum et al. 2007). Hence, the comparatively high prevalence of $P$. ciliata in conjunction with higher crab abundances and sizes may be a further factor responsible for low densities of large-sized periwinkles on the sedimentary shore.

The lack of small-sized periwinkles on the rocky shore of Helgoland is more difficult to explain. Hylleberg and Christensen (1978) show that small L. littorea may be more sensitive to wave action than larger specimens because they are less strongly adhered to rock. Hence, the higher wave exposure may be an important mortality factor for juvenile snails on the rocky shore. Additionally, low numbers of juvenile L. littorea found on Helgoland may result from the complex habitat topography at the rocky shore. Small periwinkles can retreat in deep crevices and thus are hardly detectable by an investigator. Within these crevices juvenile periwinkles may also escape predatory crabs. Behavioural changes in L. littorea in response to non-lethal crab cues (Trussell et al. 2004) suggest that juvenile periwinkles can sense remote predators and may continually hide during the summer months when predatory crabs are most abundant. This speculation is corroborated in winter samples, where periwinkles $<8 \mathrm{~mm}$ shell height are encountered 
outside crevices. However, they only constitute on average $4 \%$ of the total population (M. Molis, unpublished data). This is comparatively low to the sedimentary shore where periwinkles $<8 \mathrm{~mm}$ constitute about $40 \%$ of the total population (this study). Thus, we cannot exclude that also other factors such as competition or failing recruitment may responsible for low numbers of small $L$. littorea on Helgoland.

In summary, we conclude that the differences in shell size distribution between L. Littorea populations of the two environments result from biotic factors which mainly affect the $L$. littorea population on the sedimentary shore. We suggest that high juvenile mortality and/or failing recruitment on the rocky shore and an increased mortality of large L. littorea caused by parasitic infestation and predation in the sedimentary environment are mainly responsible for the observed differences in population structures.

Acknowledgments $\mathrm{We}$ are grateful to Caroline Eschweiler and Kathrin Voigt for assistance. Special thanks to Bettina Saier and Werner Armonies for their constructive criticism on earlier drafts of this manuscript. The project was carried out within the framework of the MarBEF Network of Excellence 'Marine Biodiversity and Ecosystem Functioning' which is funded by the Sustainable Development, Global Change and Ecosystems Programme of the European Community's Sixth Framework Programme (contract no. GOCE-CT-2003-505446). This publication is contribution number MPS-08048 of MarBEF.

\section{References}

Albrecht A (1998) Soft bottom versus hard rock: community ecology of macroalgae on intertidal mussel beds in the Wadden Sea. J Exp Mar Biol Ecol 229:85-109

Anderson MJ, Underwood AJ (1997) Effects of gastropod grazers on recruitment and succession of an estuarine assemblage: a multivariate and univariate approach. Oecologia 109:442-453

Austen I (1992) Geologisch-sedimentologische Kartierung des Königshafens (List/Sylt). Meyniana 44:45-52

Austen G (1994a) Hydrodynamics and particulate matter budget of Königshafen, southeastern North Sea. Helgol Mar Res 48:183-200

Austen I (1994b) The surficial sediments of Königshafen; variations over the past 50 years. Helgol Mar Res 48:163-171

Bartsch I, Tittley I (2004) The rocky intertidal biotopes of Helgoland: present and past. Helgol Mar Res 58:289-302

Bayerl KA, Higelke B (1994) The development of northern Sylt during the last Holocene. Helgol Mar Res 48:145-171

Bayne BL, Worrall CM (1980) Growth and production of mussel Mytilus edulis from two populations. Mar Ecol Prog Ser 3:317-328

Brown KM, Quinn JF (1988) The effect of wave action on growth in three species of intertidal gastropods. Oecologia 75:420-425

Buschbaum C (2000) Direct and indirect effects of Littorina littorea (L.) on barnacles growing on mussel beds in the Wadden Sea. Hydrobiologia 440:119-128

Buschbaum C (2002) Predation on barnacles of intertidal and subtidal mussel beds in the Wadden Sea. Helgol Mar Res 56:37-43

Buschbaum C, Reise K (1999) Effects of barnacle epibionts on the periwinkle Littorina littorea (L.). Helgol Mar Res 53:56-61

Buschbaum C, Buschbaum G, Schrey I, Thieltges DW (2007) Shell boring polychaetes affect gastropod shell strength and crab predation. Mar Ecol Prog Ser 329:123-130
Byers JE (2000) Effects of body size and resource availability on dispersal in a native and a non-native estuarine snail. J Exp Mar Biol Ecol 248:133-150

Davies MS, Knowles AJ (2001) Effects of trematode parasitism on the behaviour and ecology of a common marine snail (Littorina littorea (L.)). J Exp Mar Biol Ecol 260:155-167

Fenske C (1997) The importance of intraspecific competition in a Littorina littorea population in the Wadden Sea. Hydrobiologia 355:29-39

Fretter V, Graham A (1980) The prosobranch molluses of Britain and Denmark; Part 5 marine Littorinacea. J Moll Stud Suppl 7:241-284

Geller JB (1991) Gastropod grazers and algal colonization on a rocky shore in northern California - the importance of the body size of grazers. J Exp Mar Biol Ecol 150:1-17

Giménez L, Dick S (2007) Settlement of shore crab Carcinus maenas on a mesotidal open habitat as a function of transport mechanisms. Mar Ecol Prog Ser 338:159-168

Hadlock RP (1980) Alarm response of the intertidal snail Littorina littorea (L.) to predation by the crab Carcinus maenas (L.). Biol Bull 159:269-279

Hagmeier A (1930) Die Besiedlung des Felsstrandes und der Klippen von Helgoland. I. Der Lebensraum. Wiss Meeresunters (Abt. Helgoland) $15: 1-35$

Harger JRE (1970) The effect of wave impact on some aspects of the biology of sea mussels. Veliger 12:401-414

Hawkins SJ, Hartnoll RG (1983) Grazing of intertidal algae by marine invertebrates. Oceanogr Mar Biol Annu Rev 21:195-282

Huxham M, Raffaelli D, Pike A (1993) The influence of Cryptocotyle lingua (Digenea: Plathyelminthes) infections on the survival and fecundity of Littorina littorea (Gastropoda: Prosobranchia); an ecological approach. J Exp Mar Biol Ecol 168:223-238

Hylleberg J, Christensen JT (1978) Factors affecting the intra-specific competition and size distribution of the periwinkle Littorina littorea (L.). Natura Jütl 20:193-202

Janke K (1986) Die Makrofauna und ihre Verteilung im Nordost-Felswatt von Helgoland. Helgoländer Meeresunters 40:1-55

Janke K (1990) Biological interactions and their role in community structure in the rocky intertidal of Helgoland (German Bight, North Sea). Helgoländer Meeresunters 44:219-263

Janson K (1987) Allozyme and shell variation in two marine snails (Littorina, Prosobranchia) with different dispersal abilities. Biol J Linn Soc 30:245-256

Kemp P, Bertness MD (1984) Snail shape and growth rates: Evidence for plastic shell allometry in Littorina littorea. Proc Natl Acad Sci USA 81:811-813

Lauckner G (1984) Impact of trematode parasitism on the fauna of a North Sea tidal flat. Helgoländer Meeresunters 37:185-199

Lubchenco J (1978) Plant species diversity in a marine intertidal community: importance of herbivore food preference on algal competitive abilities. Am Nat 112:23-29

Mouritson KN, Poulin R (2002) Parasitism, community structure and biodiversity in intertidal ecosystems. Parasitology 124:101-117

Palmer AR (1990) Effect of crab effluent and scent of damaged conspecifics on feeding, growth and shell morphology of the Atlantic dogwhelk Nucella lapillus (L.). Hydrobiologia 193:155-182

Raffaelli D (1982) Recent ecological research on some European species of Littorina. J Moll Stud 48:342-354

Reichert K, Buchholz F (2006) Changes in the macrozoobenthos of the intertidal zone at Helgoland (German Bight, North Sea): a survey of 1984 repeated in 2002. Helgol Mar Res 60:213-223

Reid DG (1996) Systematics and evolution of Littorina. Ray Society, London

Reise K (1985) Tidal flat ecology. Springer, Berlin

Reise K, Herre E, Sturm M (1994) Biomass and abundance of macrofauna in intertidal sediments of Königshafen in the northern Wadden Sea. Helgoländer Meeresunters 48:201-215 
Saier B (2000) Age-dependent zonation of the periwinkle Littorina littorea (L.) in the Wadden Sea. Helgol Mar Res 54:224-229

Scherer B, Reise K (1981) Significant predation on micro- and macrobenthos by the crab Carcinus maenas L. in the Wadden Sea. Kiel Meeresforsch Sonderh 5:490-500

Seed R (1968) Factors influencing shell shape in the mussel Mytilus edulis. J Mar Biol Assoc UK 48:561-584

Seed R, Suchanek TH (1992) Population and community ecology of Mytilus. In: Gosling E (ed) The mussel Mytilus: ecology, physiology, genetics and culture. Elsevier, Amsterdam, pp 87169

Sherrell RM (1981) Intraspecific competition in the periwinkle, Littorina littorea. Biol Bull 161(2):331

Thieltges DW, Buschbaum C (2007) Vicious circle in the intertidal: Facilitation between barnacle epibionts, a shell boring polychaete and trematode parasites in the periwinkle Littorina littorea. J Exp Mar Biol Ecol 340:90-95

Trussel GC (1996) Phenotypic plasticity in an intertidal snail: the role of a common crab predator. Evolution 50:448-454

Trussel GC, Nicklin MO (2002) Cue sensitivity, inducible defence, and trade-offs in a marine snail. Ecology 83:1635-1647

Trussell GC, Ewanchuk PJ, Bertness MD (2002) Field evidence of trait-mediated indirect interactions in a rocky intertidal food web. Ecol Lett 5:241-245
Trussell GC, Ewanchuk PJ, Bertness MD (2003) Trait-mediated effects in rocky intertidal food chains: predator risk cues alter prey feeding rates. Ecology 84:629-640

Trussell GC, Ewanchuk PJ, Bertness MD, Silliman BR (2004) Trophic cascades in rocky shore tide pools: distinguishing lethal and nonlethal effects. Oecologia 139:427-432

Wahl M (1996) Fouled snails in flow: potential of epibionts on Littorina littorea to increase drag and reduce snail growth rates. Mar Ecol Prog Ser 138:157-168

Warner GF (1997) Occurrence of epifauna on the periwinkle Littorina littorea (L.), and interactions between the polychaete Polydora ciliata (Johnston). Hydrobiologia 355:41-47

Wilhelmsen U (1998) Populationsgenetik und -ökologie von drei Littorina-Arten (Gastropoda) der Nord- und Ostseeküste. Ph.D. thesis, University of Hamburg, Germany

Wilhelmsen U, Reise K (1994) Grazing on green algae by the periwinkle Littorina littorea in the Wadden Sea. Helgoländer Meeresunters 48:233-242

Wurster P (1962) Geologisches Portrait Helgolands. Die Natur 70:135-150

Yamada SB, Navarrete SA, Needham C (1998) Predation induced changes in behavior and growth rate in three populations of the intertidal snail, Littorina sitkana (Philippi). J Exp Mar Biol Ecol 220:213-226 